\begin{tabular}{c} 
Volume and Issues Obtainable at Center for Sustainability Research and Consultancy \\
Journal of Accounting and Finance in Emerging Economies \\
ISSN: 2519-0318ISSN (E) 2518-8488 \\
Volume 4: Issue 2 December 2018 \\
JSRᄃ \\
Journal homepage: publishing.globalcsrc.org/jafee \\
\hline
\end{tabular}

\title{
A Conceptual Framework for the Role of Corporate Social Responsibility in Palestinian Firm Performance
}

\author{
${ }^{1}$ Mohammed W. A. Saleh, ${ }^{2}$ Rohaida Abdul Latif, ${ }^{3}$ Fathiyyah Abu Bakar \\ ${ }^{1}$ Ph.D Scholar, Department of Tunku Puteri Intan Safinaz School of Accountancy, Universiti Utara Malaysia, \\ M.Nazzzal@hotmail.com \\ ${ }^{2}$ Associate Professor Doctor, Department of Tunku Puteri Intan Safinaz School of Accountancy, Universiti Utara \\ Malaysia, rohaida@uum.edu.my \\ ${ }^{3}$ Doctor, Department of Tunku Puteri Intan Safinaz School of Accountancy, Universiti Utara Malaysia, \\ fathiyyah@uum.edu.my
}

\begin{tabular}{|c|c|}
\hline ARTICLE DETAILS & ABSTRACT \\
\hline History & Objective: This research study has shed light on the perceptions of \\
\hline Revised format: Nov 2018 & Corporate Social Responsibility (CSR) which identified in four dimensions \\
\hline AvailableOnline: Dec 2018 & $\begin{array}{l}\text { of CSR including community, environmental, ethical, and consumer } \\
\text { protection responsibilities. }\end{array}$ \\
\hline Keywords & Methodology: This paper provides conceptual arguments that allow for \\
\hline Corporate Social & better understanding of the role of CSR in the Palestinian society. \\
\hline Responsibility, Community & Findings: The literature on CSR has increased substantially over the past \\
\hline Involvement, Environmental & decade, but existing research document mixed and inconclusive results on \\
\hline Csr, Human Resources, & the role of CSR and firm performance. \\
\hline Products and Customers & Implication: Although the link between CSR and firm performance have \\
\hline Disclosure. & $\begin{array}{l}\text { been studied, a significant research gap remains when considering the } \\
\text { relationship between CSR and firm performance in the Palestinian context. }\end{array}$ \\
\hline JEL Classification: & This is because the CSR research has been neglected in the context of \\
\hline G30,L70 & $\begin{array}{l}\text { Palestine. For companies, this study proposes that they should put more } \\
\text { efforts on enhancing the role of the CSR. Moreover, this study suggests for } \\
\text { the management to re-think and re-strategize their CSR policies to improve } \\
\text { their performance. }\end{array}$ \\
\hline
\end{tabular}

(C) 2018 The authors, under a Creative Commons Attribution-

NonCommercial 4.0

Corresponding author's email address: M.Nazzzal@ hotmail.com

Recommended citation: ${ }^{1}$ Saleh,M.W. A. ${ }^{2}$ Latif,R.A. ${ }^{3}$ Bakar,F.A. (2018). A Conceptual Framework for the Role of Corporate Social Responsibility in Palestinian Firm Performance. Journal of Accounting and Finance in Emerging Economies, 4(2) 141-150

DOI: $10.26710 /$ jafee.v4i2.527

\section{Introduction}

The corporate social responsibility (CSR) has been seen as one of the main factors that enhance the ability of firms to reach their economic goals and enhance the performance of firms. The concept of social responsibility was discussed as early as the 1930s (Carroll, 1979). Corporate social performance (CSP) model or CSR has become major philosophy for most of organization to contribute in social issues and this model developed by Carroll (1979). 
Development of this model is due to pressures in humanity and environment which has increased in business world also the purpose of this model is to decrease level of pressures occurred (Turker, 2009). Previous studies in this study indicated literature offers different definition of CSR such as Bowen (1953) which referred CSR as manager's responsible in decision making which aligned with objectives and values of society. It also can be defined as firm behavior that could affect social and nonsocial stakeholders and economic interest (Turker, 2009).

In the rapid change of economic world, organization must portray good side of them such as socially responsible organization especially in the contemporary globally competitive market. Being as socially responsible companies, this would benefit them in offering them advantages in pursuing goals especially organization that operated in multiple countries in order to avoid action taken by government in term of regulation, environmental restrictions, issues on labor exploitation. On top of that, CSR could help them in prolong their profitability and sustainability of the company also reputation in long term period (Islam, Ahmed \& Hassan, 2012).

Among most global companies, some simply view CSR as a costly and misapplication of resources and should be applied only to value-adding activities for shareholders (Lima Crisóstomo, Souza Freire \& Cortes de Vasconcellos, 2011). Nonetheless, other studies have claimed that companies have a responsibility to a broader group of stakeholders and hence should undertake the obligations inherent in CSR (Schueth, 2003). The presence of these two perspectives refers to clear inconsistencies exist in the literature review with regard to the nature of the relationship between CSR and firm performance. Some authors such as (Gherghina, Vintila, \& Dobrescu, 2015; Lima Crisostomo, de Souza Freire \& Cortes de Vasconcellos, 2011: Menassa, 2010: Nollet, Filis \& Mitrokostas, 2016) have argued that a negative relationship exists between CSR and firm performance. Yet, others such as (Alafi \& Hasoneh, 2012: Flammer, 2015: Frooman, 1997: Kotler \& Lee, 2005; Sims, 2003: Skare \& Golja, 2012: Rehman, Baloch, \& Sethi, 2015; Waddock \& Graves, 1997) claimed that CSR affects firm performance in a positive way.

In Palestine, Palestinian Securities Exchange (PSE) believes very strongly in the value of CSR that the published disclosure system issued by PSE notes that listed companies on the PSE are responsible for serving the environment and the local community as a function of their social responsibility (PSE, 2016). However, Palestinian studies argued that the disclosure of social responsibility was weak and non-existent in some of the companies listed in PSE which has a direct impact on the Palestinian society (Abu Samra, 2009; Alsenawi \& Banat, 2014). This led to misunderstand the importance of applying the CSR in the Palestinian firms. Therefore, an urgent need exists for an in-depth study into corporate social disclosure and identification of areas for improvement in the future.

Moreover, the Palestinian political situation that destroyed the state economy also considers as an incentive to study the subject of CSR of companies towards this category of society. High percentage on unemployment, pollution, socio-economic has affect Israel's occupation and policies towards Palestinian society (Palestinian Central Bureau of Statistics, 2014). This is a wake-up call for companies in helping community through social responsibility in overcome dangers arounds them (Alsenawi \& Banat, 2014). Alsenawi and Banat (2014) stated that some companies have escaped from their social responsibility for several reasons including a lack of CSR culture, no oversight role of the government in regard to CSR disclosures, and a lack of seminars and workshops. Alsenawi and Banat (2014) recommended more study to evaluate CSR projects in Palestinian society that have not yet been evaluated. Therefore, this study adopted the four-dimensional classification, which is borrowed from Usman and Amran (2015)'s study based on CSR dimensional approach including 1) community, 2) environmental, 3) ethical and 4) consumer protection responsibilities. This provides a useful means of conceptualization of CSR in emerging, yet volatile, market like Palestine. 
This paper is organized in four sections, section one is the introduction, section two is the literature review related to CSR and the underpinning theory, section three is the research model, section four is the discussion of the study, lastly section five presents the conclusion of the study.

\section{Literature Review}

In their review of the historical development of Corporate Social Responsibility, Usman and Amran (2015) identified four dimensions of CSR based on CSR dimensional approach, including: 1) community, 2 ) environmental, 3) ethical and 4) consumer protection responsibilities. Community responsibility refers to the contribution of the company to the general welfare of society and improvements in the personnel department leading to the improvement of production capacity, which thus leads to improvement of the performance of the company as a whole (Lakhder \& Shanini, 2011). Environmental responsibility is related to the reduction of the environmental impacts of production processes and the elimination of toxic emissions and waste (Muhammad, Scrimgeour, Reddy \& Abidin, 2015). Ethical responsibility refers to working with an ethic framework within institutions to prevent bribes and corruption, protect consumer rights, and make ethical investments. Lastly, consumer protection is related to the non-manipulation of prices and preventing monopoly products (Carroll, 1999).

\subsection{The Concept of Corporate Social Responsibility}

Palmer (2012) stated that recently many well-known international companies have added CSR programs to their business operations as CSR has become a fundamental priority in current society. However, focusing on the question about whether CSR or firm performance comes first remains vital. Waddock and Graves (1997) and Dean (1999) analysed this question by applying the slack resource theory and the good management theory. According to slack resource theory, a firm should obtain a good financial level first so that they can later engaged in corporate social responsibility. That is because to engaged social responsibility, funds are needed from successful firm performance. Based on this theory, then, firm performance should come first.

Conversely, stakeholder theory states that social responsibility should come first. This theory explains that a company should first build a good reputation, which will, in turn, help a company to achieve good firm performance (Waddock \& Graves, 1997) Stakeholder theory also emphasizes that, when firms voluntarily release pertinent information on their social and environment, they can be better positioned. Thus, the profitability of a firm is seen as contingent upon the ability of the firm to achieve its social and economic objectives (Frooman, 1997). This means that corporate social responsibility comes first.

Many scholars have studied the relationship between CSR and firm performance. Alafi and Hasoneh's (2012) study of banks in Jordan showed that CSR and was related positively with customer satisfaction and customer satisfaction, in turn, was related with firm performance and sustainable business practices. Husted and Allen (2000) found that the CSR can be viewed as a source to enhance the firm performance of a company, and create competitive advantage, and was important for increasing customer confidence and satisfaction. Moreover, Kotler and Lee (2005) and Sims (2003) found a clear positive relationship between CSR and firm performance, whereby CSR leads to profitability in the long run.

Study by Skare and Golja in 2012 on CSR indicated most of companies that employed CSR in their organization have better reputation and performance compared to non-CSR companies based on companies under Dow Jones Global Stock Market Index. Furthermore, findings on a study by Skare and Golja (2012) showed CSR could affect them through primary stakeholder that could be profitable and beneficial especially China firms. In a study of firms listed on Karachi Stock Exchange on cement sector firms indicated positive relationship between organization performance and performance of CSR firm also it could affect organization sustainability in long-term in achieving benefits and objectives of monetary (Rehman, Baloch and Sethi, 2015). 
Several reasons have been articulated for increased profitability of firms practicing CSR. Flammer (2015), in his study of average public firms in the U.S. economy, found that the adoption of CSR proposals was associated with an increase in labour productivity and sales growth, thus, improving firm performance. Also, Hasan, Kobeissi, Liu, and Wang (2016) clearly showed that CSR in manufacturing industry firms in the United States created value beyond its costs that led to good firm performance.

Nonetheless, several factors exist that give pause to suggesting that CSR is always related to enhance firm performance. Gherghina, Vintila, and Dobrescu (2015) found a significant and negative relationship between corporate social responsibility and firm size; this negative impact can occur due to expenses incurred by CSR activity that reduce a company's capital and thus weaken firm performance, which is especially concerning for a small company. Study on CSR by Nollet et al. (2016) discovered significant and negative relationship between corporate social performance and return of capital in short term. Nevertheless, it is arguably on CSR which CSR expenditures only pays off after CSP threshold reached although it serves on stakeholders' interest, long-term planning and resources.

Previous study on CSR by Lima Crisostomo et al. (2011) indicated negative relationship between CSR and value of firm based on 78 companies which listed on Brazilian stock market. Therefore, relationship between firm performance and CSR showed positive relationship that could increase profits and wealth of shareholder also this would contribute on firm sustainability in long-term.

In summary, based on previous literature review, inconsistencies exist in studies about the relationship between the CSR and firm performance, and the results remain inconclusive, thus, need more study efforts.

\subsubsection{Community Involvement CSR}

The application of social responsibility has been found to be related to greater labour productivity and sales growth (Flammer, 2015), and better performance is seen an outcome of the significant relationship between CSR and societal progress (Lakhder \& Shanini, 2011). Moreover, research has shown that disclosed socially related information about funding raising, charity donations, medical scholarship and health care by UK companies supports social development (Lal Joshi \& Gao, 2009). By disclosing this information, firms can develop brand image at a lower cost as compared to public relations and advertising. Hence, such activities are well related to company performance. According to Ako, Obokoh, and Okonrnah (2009), companies throughout the world enhance their performance via meeting the societal values of their host community. Furthermore, Jones (1995), Lakhder and Shanini (2011), and Palmer (2012) found a positive relationship between the implementation of community activities and firm performance

On the other hand, previous literature has suggested that CSR is negatively related to firm performance, such findings contradict with the stakeholder theory where it suggests that the CSR efforts are done in the interest of stakeholders with the aim of benefiting shareholders (Jones, 1995). For example, Menassa (2010) conducted similar research and found that Lebanese companies put a greater significance on community involvement; however, no evidence showed a relationship between community involvement and firm performance. Furthermore, Nollet et al. (2016) found a negative relationship between payment for social activities and the return on capital. Besides, Gherghina et al. (2015) found a significant negative relationship between corporate social responsibility and firm size, hence, leading to a negative impact on firm's performance.

\subsubsection{Environmental CSR}

In recent years, there has been increasing pressure to enact and adopt effective legislations concerning environmental conservation in countries around the globe. In response to this, companies are adopting strict initiatives dedicated to the reduction of emissions, fully expectant of future policy and developments in society and competitiveness when it comes to the environment. Moreover, the pressure on offering environmental friendly products, processes, and services have made firms realize the significance of 
adopting environmental sustainability standards in the long-run (Haladu \& Salim, 2017). This has brought about green resources/capabilities and compliance development coupled that are all at par with international standards like ISO 14000, OHSAS 18000 as well as other relevant legislations pertaining to the environment (Mishra \& Suar, 2010).

Inconsistencies exist in the literature on environmental CSR and its possible influence on the firm performance of corporations. Some have argued that these mixed results might be partly due to the difficulty of measuring environmental performance (King \& Lenox, 2001; Margolis \& Walsh, 2003; Russo \& Fouts, 1997).

According to Kuo, Huang, and Wu (2010), a clear positive relationship exists between the efficiency of a firm's operations and environmental disclosure. Environmental disclosure has been seen to have a significant relationship with environmental management costs of a firm, net profits and the economic advantages of environmental management with firm performance. Majority of studies have evidenced the positive environmental CSR disclosure-firm performance relationship as it mitigates environmentalrelated costs, raw material wastes and inefficient processes of production (Haniffa \& Cooke, 2005; Lakhder \& Shanini, 2011; Mishra \& Suar, 2010; Muhammad Scrimgeour et al., 2015). These findings are in sync with stakeholder theory which posits that environment can considered as one of the main primary factors that can impact the operations that target fulfilling the strategic purpose of a firm (Hannan \& Freeman, 1984).

In contrast, several studies have shown a weak relationship between environmental CSR and firm performance. Dragomir (2009) investigated 60 of the largest European Union industrial groups in Europe. The result shows that no significant relationship existed between environmental performance and firm performance and environmental disclosure and firm performance. Along the same line, Menassa (2010) found that the relationship between environmental disclosure and firm performance was not strong in a study of Lebanese commercial banks, and Magness (2006) also found the same result from the study in Canada.

\subsubsection{Human Resource CSR}

Human resources are considered as intellectual property that drives organizational value and human resources CSR has been related to considerable firm performance results and the effectiveness of the organization (Menassa, 2010). CSR of human resources also promotes employee commitment, motivation and loyalty and eventually the internal resources and capabilities development, particularly those related to employees (Branco \& Rodrigues, 2006). In this regard, employees that are motivated and loyal tend to actively work towards goal achievement for reasons that are not linked to the advantages that they can reap from extrinsic rewards, but rather they want to maintain a good relationship with their employers and the organization they work in as explained by Skudiene and Auruskeviciene (2012). The authors also evidenced that responsible training mitigates turnover and absenteeism among employees.

In a related study, human resource initiatives were evidenced to be one of the ethical dimensions of decision making when it comes to human resource development (Guadamillas-Gomez \& DonateManzanares, 2011). In this regard, the investment quality and extent in establishing policies of workercentered employment (e.g., higher remuneration, pension and gratuity, welfare, training quality, health and safety and equal opportunities) have a tendency to mitigate issues that are linked with organizational labor cost, and employee absenteeism and rate of turnover (Carrol, 1999; Samy, Odemilin \& Bampton, 2010). In fact, employee justice theories have been cited by scholars to reinforce the perception of fairness level illustrated by the firm towards their employees. Scholars have argued that through social responsibility initiative of employees, the organization can establish a good moral relationship with employees and are enabled to employ, maintain and prevent skilled and experienced employees from quitting the firms (Galbreath, 2009). However, some other studies like Crisostomo et al. (2011) revealed a negative effect of the social action of employees on the firm performance. 


\subsubsection{Products and Customers Disclosure}

Both product and customer CSR initiatives have been revealed to have a significant effect on the performance of firms. Although these initiatives assist in building knowledge of customers, it is a largely overlooked dimension in literature. This CSR dimension boosts organizations' concentration on ethical issues and good practices that are linked to products, services, and customers for sustained market status (Galbreath, 2009).

Among the studies, the common initiatives include investing in product quality and innovation, customer satisfaction, providing support for physically challenged customers, clarifying and adopting operational ethics, contributing to society for change and adhering to laws and norms (e.g., Carrol, 1999; Rashid, 2010). Therefore, global businesses are increasingly integrating the above mentioned initiatives to support their major economic objectives to produce higher profits via the addition of consumer's emotional, social and functional values (Menassa, 2010). When each of these elements is changed, it can either improve or degrade the company's perceived product value as perceived by the customers.

\subsection{Underpinning Theory}

Stakeholder theory provides the underpinning support on how CSR affect the firms' performance. The main objective of an organization is solely to construct value for a firm so that the shareholders' wealth is maximized, and no obligation is owed to the community (Friedman, 1970). Stakeholders are defined as any person or group who can influence or are influenced by the success of the firm's objectives (Hannan \& Freeman, 1984). Bryson (2004) described the stakeholders as individuals, groups or organizations that must be considered by managers and leaders to the triumph and survival of the corporation.

Furthermore, Stakeholder theory utilizes all external and internal relationship for organization and regulates these relationships that will affect the survival of the organization because the most fundamental goal of any organization is to survive (Hannan \& Freeman, 1984). Large spectrum of stakeholders can be categorized into six primary groups- consumers, employees, shareholders, community, environment and government as well as groups like trade unions, suppliers, competitors and business associates (Mullins, 2002). Based on the discussion earlier, stakeholders represent all agents that are interested in the company's operations or any individual or group who can influence or is influenced by the operations that aim to accomplish the strategic objectives of the organization (Hannan \& Freeman, 1984).

Hannan and Freeman (1984) also suggests that the managers must comprehend stakeholder's groups' needs in formulating corporate objectives so that the firm would obtain essential support for its continuous survival. Stakeholder theory suggests that managers require support from the stakeholder's groups while stakeholder's groups acquire satisfaction from the actions of the firm. The success of a firm is influenced by the systematic managerial attention to the interests of the stakeholders (Hannan \& Freeman, 1984).

Stakeholder theory also suggests that the sustained existence of a firm requires the help of its stakeholders and their assent must be pursued and the corporation's activities be modified to meet their anticipation (Cotter \& Najah, 2011). Hence, a healthy image of the companies is portrayed by the management of the firms to make them successful.

In short, the theory assumes that the business objectives of a firm can be easily accomplish if it has good and strong relationship with other interest groups. As a result, when firms voluntarily release more information on their social and environment, they can be better positioned. In this standpoint, it is suitable to apply stakeholder theory in examining the level of corporate social responsibility information revealed to stakeholders and corporate firm performance in Palestine.

\section{Research Model}


In Figure 1 the research framework of this study has been demonstrated. According to the Figure, the independent variable is the CSR. This study adopted the four-dimensional classification, which is borrowed from Usman and Amran (2015)'s study based on CSR dimensional approach including 1) community, 2) environmental, 3) ethical and 4) consumer protection responsibilities. Based on the stakeholder theory states, when firms voluntarily release pertinent information on their social and environment, they can be better positioned. Thus, the profitability of a firm is seen as contingent upon the ability of the firm to achieve its social and economic objectives.

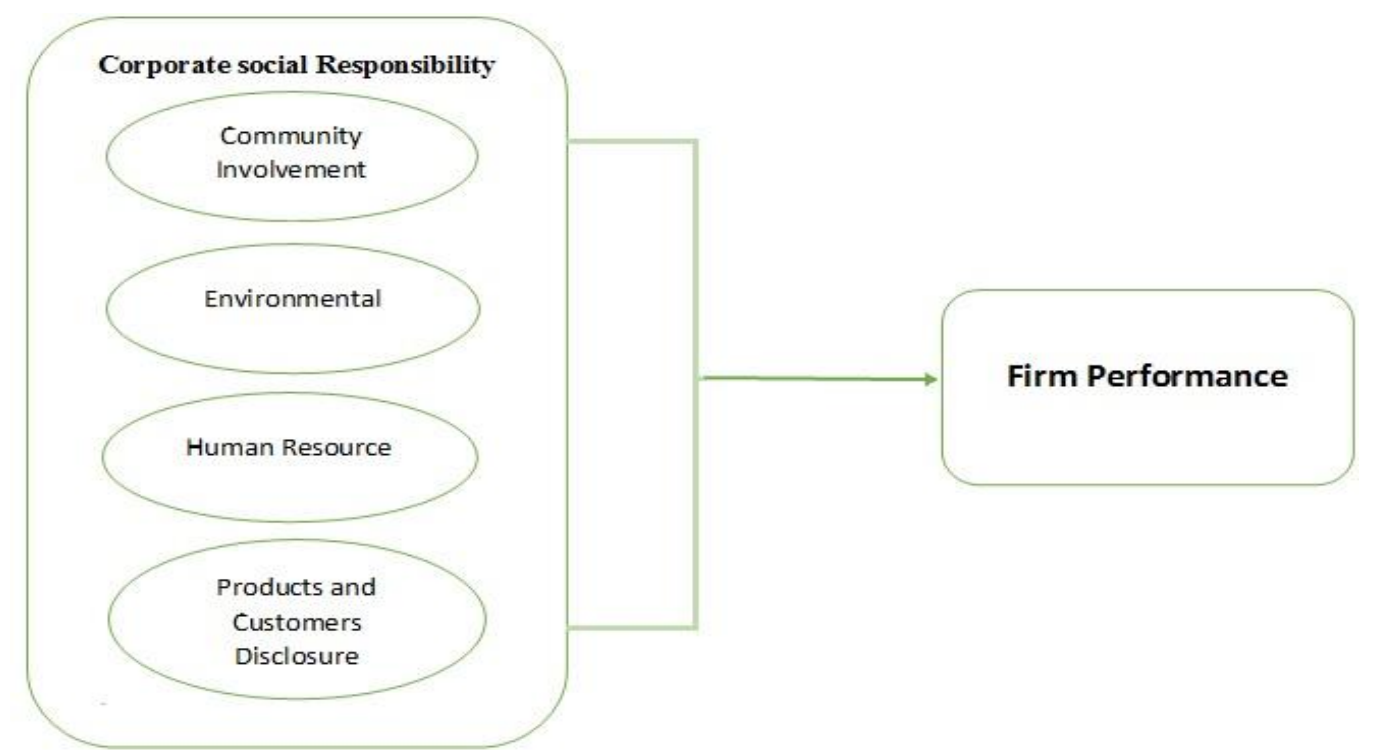

Figure 1

Research Framework.

Previous studies on the relationship between CSR and firm performance produced mixed results. Many studies found that the CSR is costly and misapplication of resources, and other studies found that the CSR practices should undertake the obligations inherent in CSR that leads to profitability in the long run. This inconsistent result signal the existence of black-box in the relationship which needs to be resolved.

\section{Discussions}

This study suggests the relationship between CSR and firm performance. By reviewing previous literature, the results indicate that the relationships between CSR and firm performance have mixed results. The first group was in line with the Stakeholder theory which emphasizes that, when firms voluntarily release pertinent information on their social and environment, they can be better positioned. Thus, the profitability of a firm is seen as contingent upon the ability of the firm to achieve its social and economic objectives. However, many studies revealed that CSR activities are costly and misapplication of resources due to expenses incurred by CSR activity that reduce a company's capital and thus weaken firm performance.

Therefore, depending on the stakeholder theory, the existence of CSR has a direct positive relationship with firm performance, which leads to maximize profits and increase shareholder wealth. As results, the CSR toward primary stakeholders can be profitable and beneficial to the firms, as the CSR efforts contribute to firm sustainability in long-run development and help to achieve the monetary objectives and benefits.

Thus, this study would contribute on the knowledge of CSR and how it affects firm performance especially in emerging and volatile market such as Palestine also it would contribute to literature gap which related to CSR environmental, ethical and responsibilities on consumer protection towards organization performance. This could be used to better understand the relationships among the variables 
under review. This study fills the literature gaps by focusing on the CSR activities more especially in emerging, yet volatile economies such as Palestine where literature of the kind is lacking.

\section{Conclusion}

This study discussed the role of CSR which identified in four dimensions of CSR including 1) community, 2) environmental, 3) ethical and 4) consumer protection responsibilities. Stakeholder theory provides that a company by the CSR disclosures could build a good reputation, which will, in turn, help a company to achieve good firm performance. Therefore, based on this theory, the study predicts that CSR activities can positively affect firm performance. It is recommended that the government collaborate with agencies, both private and public, in consideration of CSR framework and database requirements in order to provide direction to the country's social and environmental reporting. This paper recommends for empirical studies on the effect of CSR and firm performance. It also recommends the other CSR dimensions should be adopted in the subsequent studies such as economic responsibilities, voluntariness responsibilities, legal responsibilities to better understand the relationship between CSR and firm performance due to the inconsistent results.

\section{References}

Abu Samra, H. (2009). Obstacles disclosure of social responsibility in reports of public shareholding companies listed on the Palestine Exchange, from the perspective of auditors and corporate management. Master Thesis, Gaza: The Islamic University.

Alafi, K., \& Hasoneh, A. B. (2012). Corporate social responsibility associated with customer satisfaction and firm performance a case study with Housing Banks in Jordan. International Journal of Humanities and Social Science, 2(15), 102-115.

Albatayneh, R. M. S. (2014). The effect of corporate sustainability performance on the relationship between corporate efficiency strategy and corporate firm performance (Doctoral dissertation, Universiti Utara Malaysia).

Alsenawi, A. M. A., \& Banat, B. Y. I. (2014). Corporate Social Responsibility (CSR): Palestine Exchange. European Scientific Journal, 10(35).

Bowen, H. R., \& Johnson, F. E. (1953). Social responsibility of the businessman. Harper.

Bryson, J. M. (2004). What to do when stakeholders matter: stakeholder identification and analysis techniques. Public management review, 6(1), 21-53.

Carroll, A. B. (1979). A three-dimensional conceptual model of corporate performance. Academy of management review, 4(4), 497-505.

Carroll, A. B. (1999). Corporate social responsibility: Evolution of a definitional construct. Business \& society, 38(3), 268-295.

Castelo Branco, M., \& Lima Rodrigues, L. (2006). Communication of corporate social responsibility by Portuguese banks: A legitimacy theory perspective. Corporate Communications: An International Journal, 11(3), 232-248.

Cotter, J., \& Najah, M. M. (2012). Institutional investor influence on global climate change disclosure practices. Australian journal of management, 1-19.

Dean, K. L. (1998). The chicken and the egg revisited: Ties between corporate social performance and the financial bottom line. The Academy of Management Executive, 12(2), 99-100.

Flammer, C. (2015). Does corporate social responsibility lead to superior firm performance? A regression discontinuity approach. Management Science, 61(11), 2549-2568.

Frooman, J. (1997). Socially irresponsible and illegal behavior and shareholder wealth a meta-analysis of event studies. Business \& society, 36(3), 221-249.

Galbreath, J. (2009). Building corporate social responsibility into strategy. European business review, 21(2), 109-127. 
Gherghina, Ş. C., Vintilă, G., \& Dobrescu, D. (2015). An empirical research on the relationship between corporate social responsibility ratings and US listed companies' value. Journal of Economics Studies and Research, Vol. 2015, 1-12.

Guadamillas-Gómez, F., \& Donate-Manzanares, M. J. (2011). Ethics and corporate social responsibility integrated into knowledge management and innovation technology: A case study. Journal of Management Development, 30(6), 569-581.

Haladu, A., \& Salim, B. B. (2017). Sustainability Reporting by Firms in the Nigerian Economy: Social versus Environmental Disclosure. Journal of Accounting and Finance in Emerging Economies, $3(2), 87-112$.

Haniffa, R. M., \& Cooke, T. E. (2002). Culture, corporate governance and disclosure in Malaysian corporations. Abacus, 38(3), 317-349.

Haniffa, R. M., \& Cooke, T. E. (2005). The impact of culture and governance on corporate social reporting. Journal of accounting and public policy, 24(5), 391-430.

Hannan, M. T., \& Freeman, J. (1984). Structural inertia and organizational change. American sociological review, 149-164.

Hasan, I., Kobeissi, N., Liu, L., \& Wang, H. (2016). Corporate social responsibility and firm firm performance: the mediating role of productivity. Journal of Business Ethics, 1-18.

Husted, B. W., \& Allen, D. B. (2000). Is it ethical to use ethics as strategy?. Journal of Business Ethics, 27(1-2), 21-32.

Islam, Z. M., Ahmed, S. U., \& Hasan, I. (2012). Corporate social responsibility and firm performance linkage: Evidence from the banking sector of Bangladesh. Journal of Organizational Management, 1(1), 14-21.

Jackling, B., \& Johl, S. (2009). Board Structure and Firm Performance: Evidence from India's Top Companies. Corporate Governance: An International Review, 17, 4, 492-509.

Jones, T. M. (1995). Instrumental stakeholder theory: A synthesis of ethics and economics. Academy of management review, 20(2), 404-437.

King, A. A., \& Lenox, M. J. (2001). Does it really pay to be green? An empirical study of firm environmental and financial perform

Kuo, L., Kevin Huang, S., \& Jim Wu, Y. C. (2010). Operational efficiency integrating the evaluation of environmental investment: the case of Japan. Management Decision, 48(10), 1596-1616.

Lakhder, A., M. and Shanini, H., (2011). "The impact of the adoption of social responsibility on firm's firm performance", Ouargla University journal, Algeria, 22(2), 227-245.

Lal Joshi, P., \& Gao, S. S. (2009). Multinational corporations' corporate social and environmental disclosures (CSED) on web sites. International journal of commerce and management, 19(1), 27 44.

Lima Crisóstomo, V., de Souza Freire, F., \& Cortes de Vasconcellos, F. (2011). Corporate social responsibility, firm value and firm performance in Brazil. Social Responsibility Journal, 7(2), 295-309.

Magness, V. (2006). Strategic posture, firm performance and environmental disclosure: An empirical test of legitimacy theory. Accounting, Auditing \& Accountability Journal, 19(4), 540-563.

Margolis, J. D., \& Walsh, J. P. (2003). Misery loves companies: Rethinking social initiatives by business. Administrative science quarterly, 48(2), 268-305.

Menassa, E. (2010). Corporate social responsibility: An exploratory study of the quality and extent of social disclosures by Lebanese commercial banks. Journal of Applied Accounting Research, 11(1), 4-23.

Mishra, S., \& Suar, D. (2010). Does corporate social responsibility influence firm performance of Indian companies?. Journal of business ethics, 95(4), 571-601.

Moneva. J.\& Ortas, E., (2010). Corporate environmental and firm performance: a multivariate approach, Industrial Management \& Data Systems. International Journal of Social Economics, 110(2), 193 210. 
Muhammad, N., Scrimgeour, F., Reddy, K., \& Abidin, S. (2015). The relationship between environmental performance and firm performance in periods of growth and contraction: evidence from Australian publicly listed companies. Journal of Cleaner Production, 102, 324-332.

Nollet, J., Filis, G., \& Mitrokostas, E. (2016). Corporate social responsibility and firm performance: A non-linear and disaggregated approach. Economic Modeling, 52, 400-407.

Palmer, H. J. (2012). Corporate Social Responsibility and Firm performance: Does it Pay to Be Good?, CMC Senior Theses. Paper 529.

Philip, K., \& Lee, N. (2005). Corporate social responsibility: Doing the most good for your company and your cause. Resource Policy, 27, 61-75.

Rashid, M., Abdeljawad, I., Manisah Ngalim, S., \& Kabir Hassan, M. (2013). Customer-centric corporate social responsibility: A framework for Islamic banks on ethical efficiency. Management Research Review, 36(4), 359-378.

Rehman, A., Baloch, Q. B., \& Sethi, S. (2015). Understanding the relationship between Firm's Corporate Social Responsibility and Firm performance: Empirical Analysis. Abasyn University Journal of Social Sciences, 8(1), 98-110.

Russo, M. V., \& Fouts, P. A. (1997). A resource-based perspective on corporate environmental performance and profitability. Academy of management Journal, 40(3), 534-559.

Samy, M., Odemilin, G., \& Bampton, R. (2010). Corporate social responsibility: a strategy for sustainable business success. An analysis of 20 selected British companies. Corporate Governance: The international journal of business in society, 10(2), 203-217.

Schueth, S. (2003). Socially Responsible Investing in the United States. Journal of Business Ethics, 43(3), 189-194.

Sims, R. R. (2003). Ethics and corporate social responsibility: Why giants fall. Greenwood Publishing Group.

Skare, M. and Golja, T. (2012). Corporate Social Responsibility and Corporate Firm performance - Is there a Link? Economic Research- Ekonomska Istrazivanja. 25(1), 215-242.

Skudiene, V., \& Auruskeviciene, V. (2012). The contribution of corporate social responsibility to internal employee motivation. Baltic journal of management, 7(1), 49-67.

Temitope Ako, R., Ogechukwu Obokoh, L., \& Okonmah, P. (2009). Forging peaceful relationships between oil-companies and host-communities in Nigeria's Delta region: A stakeholder's perspective to corporate social responsibility. Journal of Enterprising Communities: People and Places in the Global Economy, 3(2), 205-216.

Turker, D. (2009). Measuring corporate social responsibility: A scale development study. Journal of business ethics, 85(4), 411-427.

Usman, A. B., \& Amran, N. A. B. (2015). Corporate social responsibility practice and corporate firm performance: evidence from Nigeria companies. Social Responsibility Journal, 11(4), 749-763.

Waddock, S. A., and S. M. Graves. (1997). The corporate social performance Firm performance link. Strategic Management Journal 18 (4): 303- 319. 